THE KURUME MEDICAL JOURNAL Vol. 9, No. 1, 1962

\title{
SOME PROPERTIES OF ECHO AND COXSACKIE VIRUSES IN TISSUE CULTURE AND VARIATIONS BY HEAT
}

\author{
SHIGERU YAMAMATO AND MASAHISA SHINGU \\ Department of Microbiology, Kurume University School of Medicine, \\ Kurume, Japan
}

\section{INTRODUCTION}

Although considerable attention should be paid to the studies on the properties of ECHO and Coxsackie viruses, there is as yet very little information as to the general properties of the viruses in the tissue culture. It was necessary to make clear the fundamental conditions for the various experiments followed in this laboratory.

The present paper deals with the multiplication of viruses in tissue culture and the tolerance experiments for heat treatment in order to remove the simian viruses, and furthermore, the variations occuring in viruses which survived through the heat treatment.

\section{MATERIAL AND METHODS}

\section{Tissue culture.}

MS, FL and HeLa cells as the established cell lines and primate monkey kidney (MK) cell were used in the present experiments. The cells were grown in bottles or tubes with $\mathrm{M}+$ Hanks solution containing $10 \%$ bovine serum for the establiehed cell lines and $3 \%$ for MK cell (growth medium) at the temperature of $37^{\circ} \mathrm{C}$. Puck's solution was used for washing the cultures and for diluting the virus. As the maintenance medium, M + Earle's solution added $10 \%$ skim milk solution (10 $\%$ ) was used.

\section{Viruses.}

The viruses used in the present studies were ECHO 1, 2, 3, 5, 6, 7, 9, 11 and 12, and Coxsackie B1, B2, B3, B4 and B5. Mahoney and Sabin strains of type I poliovirus were used as a control for plaque experiment because of the formation of a well-defined one on the cell menolayers. Stock virus was propagated in MK cell monolayers in the cysteine medium and harvested after one or two days of incubation at $37^{\circ} \mathrm{C}$. The culture was frozen and thawed to disrupt cells and centrifuged. Supernatant fluid was stored at $-20^{\circ} \mathrm{C}$ until used.

Titration of viruses.

Forming the cell monolayers in tubes, the growth medium was replaced with maintenance medium after washing once with Puck's solution. Virus inoculation 
was done after 24 hours and three tubes were used for each 10 -fold dilution of viruses. The cytopathogenic effects by viruses were observed during 9 days and $\mathrm{TCD}_{50}$ end points calculated.

\section{Plaque formation.}

The cell monolayer grown in the bottle was washed once with Puck's solution, maintenance medium added, and virus inoculation was done after 24 hours. After removal of the maintenance medium, the monolayer was washed with Puck's solution and inoculated with $0.2 \mathrm{ml}$ of appropriate dilutions of viruses in Puck's solution. After adsorption for 1 hour, agar overlay was added. The overlay consisted of $1.5 \%$ agar (Difco Bacto) in Hank's BSS containing $2 \%$ calf serum $0.22 \%$ sodium bicarbonate and neutral red at a concentration of $1: 60,000$. In the case in which MK cell was used, Earle's solution was substituted for Hank's BSS. After the agar had solidified, the bottles were kept at $37^{\circ} \mathrm{C}$ for 3 or 5 days. The number and the size of plaques were observed.

\section{RESULTS}

\section{Cell susceptibility to viruses.}

To test the susceptibility of cells to ECHO and Coxsackie viruses, titrations were performed using MK, MS, FL and HeLa cells.

Table 1 gives the results of titrations of the same pool of each virus with the cells indicated and the ratio of titer with $\mathrm{HeLa}$ (MS, MK) cell to that with FL cell.

TABLE 1

Titration of ECHO and Coxsackie viruses

\begin{tabular}{|c|c|c|c|c|c|c|c|c|c|}
\hline \multirow{2}{*}{\multicolumn{3}{|c|}{ virus }} & \multicolumn{4}{|c|}{ cell } & \multirow{3}{*}{$\frac{\mathrm{HeLa} / \mathrm{FL}}{1.3}$} & \multirow{3}{*}{$\frac{\mathrm{MS} / \mathrm{FL}}{2.0}$} & \multirow{3}{*}{$\frac{\mathrm{MK} / \mathrm{FL}}{3.0}$} \\
\hline & & & \multirow{2}{*}{$\frac{\text { HeLa }}{5.5^{*}}$} & \multirow{2}{*}{$\frac{\text { MS }}{6.2}$} & \multirow{2}{*}{$\frac{\mathrm{MK}}{7.2}$} & \multirow{2}{*}{$\begin{array}{l}\mathrm{EL} \\
4.2\end{array}$} & & & \\
\hline $\mathrm{ECHO}$ & 1 & & & & & & & & \\
\hline " & 2 & & 6.2 & - & 6.5 & 5.5 & 0.7 & - & 1.0 \\
\hline " & 3 & & 5.8 & - & $>7.5$ & - & - & - & - \\
\hline " & 5 & & 5.5 & 6.2 & 6.8 & 5.2 & 0.3 & 1.0 & 1.6 \\
\hline " & 6 & & 6.2 & 6.9 & 6.8 & 5.5 & 0.7 & 1.4 & 1.3 \\
\hline " & 7 & & 6.2 & 7.2 & $>7.5$ & 6.2 & 0 & 1.0 & $>1.3$ \\
\hline " & 9 & & 5.5 & 6.5 & 6.2 & 5.2 & 0.3 & 1.3 & 1.0 \\
\hline " & 11 & & 5.2 & 5.5 & 6.2 & 5.8 & -0.6 & -0.3 & 0.4 \\
\hline " & 12 & & 5.2 & 5.9 & 7.2 & 6.2 & -1.0 & -0.3 & 1.0 \\
\hline Coxsac & kie & B 1 & 6.5 & 6.5 & 5.8 & 7.2 & -0.7 & -0.7 & -1.4 \\
\hline " & & B 2 & 7.2 & 8.2 & 7.2 & 7.2 & 0 & 1.0 & 0 \\
\hline " & & B3 & 5.8 & 7.2 & 5.5 & 4.8 & 1.0 & 2.4 & 0.7 \\
\hline " & & B 4 & 5.5 & 5.9 & 4.5 & 5.8 & -0.3 & 0.1 & -1.3 \\
\hline " & & B5 & 5.8 & 6.2 & 5.5 & 6.8 & -1.0 & -0.6 & -1.3 \\
\hline
\end{tabular}

* $\log _{10}$ titer per $1 \mathrm{ml}$ 
Each virus represents different titers for different cells. The titer of ECHO 1 is 7.2 and 4.7 in $\log _{10}$ unit in the case of $\mathrm{MK}$ and FL cells, respectively. There is, therefore, a difference of 1000 fold between both cases. Thus, the susceptibility to viruses is more or less different with the cells used, but it is seemed advantageous in general to adopt MK or MS cells for titrating these viruses.

The multiplicatjon of viruses in cell monolayers.

To inspect the feature of the multipication of viruses in various cells, MK, MS and FL cells and ECHO 3, 9, 11 and 12 and Coxsackie B1, B2, B3, B4 and B5 viruses were selected for this experiment.

The maintenance medium was removed and the monolayers washed. The cultures were inoculated with $0.5 \mathrm{ml}$ of virus solution corresponding to an input multiplicity of $1-3$. One bottle contained approximately $4 \times 10^{5}$ cells.

The virus was allowed to adsorb for 1 hour at room temperature, the cultures were washed twice with Puck's solution, and incubated at $37^{\circ} \mathrm{C}$ after adding the maintenance medium. At each time interval of 3 hours, the bottle was taken out and frozen. After two cycles of freezing-thawing, the whole culture was centrifuged and the supernatant fluid was titrated using MS cell. The results are illustrated graphically in Fig. 1 and 2 as $\log _{10}$ titers against the incubation time.

Generally speaking, the viruses began to multiply after 6 hours of incubation, and reached the maximum after about 12 hours and thereafter remained constant. The yields of viruses were lower in the MK cell than in MS or FL cells, and approximately 300 particles on the average were produced per infected cell.

Fig. 1. Growth curve of ECHO viruses in MS, MK and FL cells.

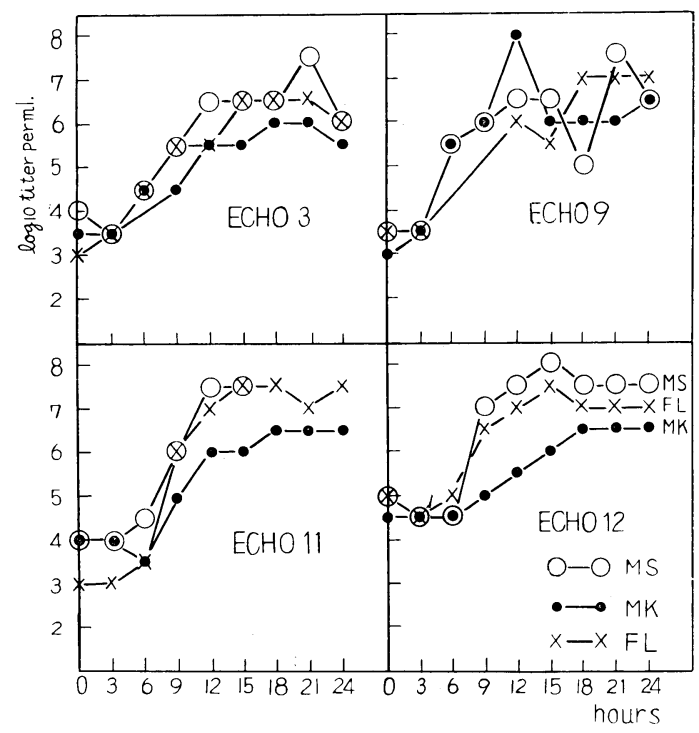

Flaque formation of ECHO and Coxsackie viruses.

Though it was shown that ECHO and Coxsackie viruses used in the present 
Fig. 2. Growth curve of Coxsackie viruses in MS, MK and FL cells.

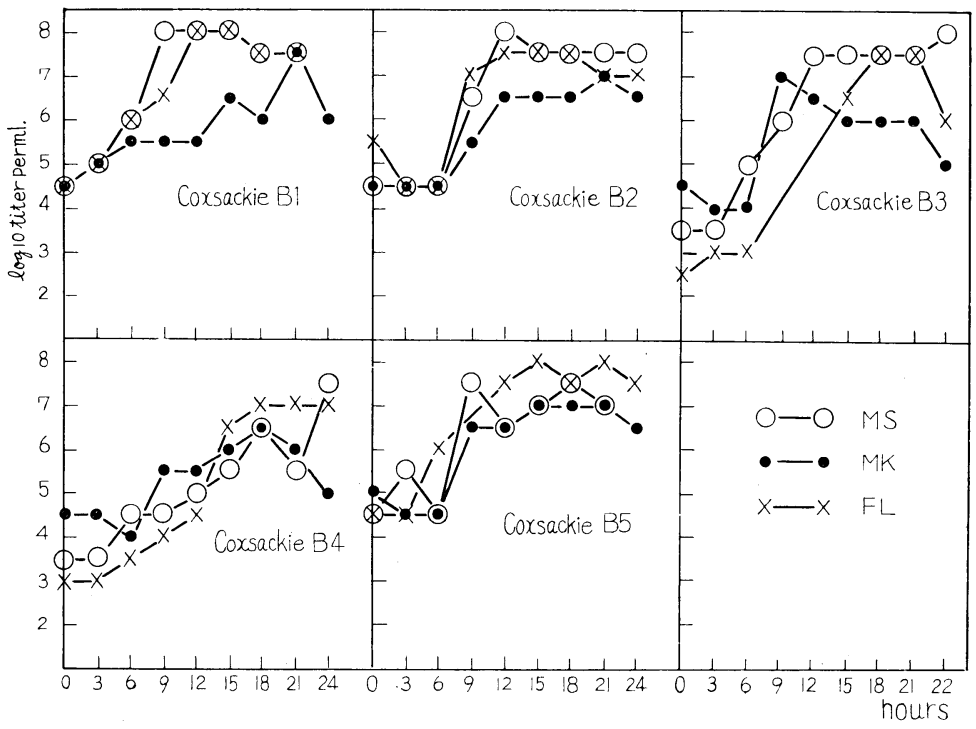

TABLE 2

Plaque fomration of ECHO and Coxsackie viruses

\begin{tabular}{|c|c|c|c|c|c|c|}
\hline \multirow{2}{*}{\multicolumn{3}{|c|}{ virus }} & \multicolumn{4}{|c|}{ cell } \\
\hline & & & \multirow{2}{*}{$\frac{\text { HeLa }}{0.5-3.0^{*}}$} & \multirow{2}{*}{$\frac{\text { FL }}{0.3}$} & \multirow{2}{*}{$\begin{array}{l}\text { MS } \\
\mathrm{p}^{* *}\end{array}$} & \multirow{2}{*}{$\frac{\mathrm{MK}}{2 \cdot 0-3 \cdot 0^{\prime \prime}}$} \\
\hline ECHO & 1 & & & & & \\
\hline " & 2 & & - & - & - & - \\
\hline " & 3 & & $2.0^{\prime \prime}$ & - & - & $2 \cdot 0-3 \cdot 0^{\prime \prime}$ \\
\hline " & 5 & & - & - & - & $2.0-3,0^{\prime \prime}$ \\
\hline " & 6 & & 2.0 & - & - & - \\
\hline " & 7 & & $1.0-2.0$ & - & $0.2-1.0^{\prime}$ & 2. $0-3.0^{\prime \prime}$ \\
\hline " & 9 & & - & 0.5 & - & - \\
\hline " & 11 & & $2.0-3.0$ & 1.0 & $\mathrm{p}-0.2$ & - \\
\hline " & 12 & & 1. $0-4.0^{\prime \prime}$ & $0.5-1.5^{\prime}$ & $0.2-1.0$ & - \\
\hline Coxsac & kie & B 1 & 1. $0-2.0$ & 0.5 & $0.3-3.0$ & 2. $0^{\prime \prime}$ \\
\hline " & & B 2 & 1.5 & 1. $0^{\prime \prime}$ & 0.3 & 1. $0^{\prime \prime}$ \\
\hline " & & B 3 & 1.0 & $0.5-1.0$ & $0.3-1.0$ & 1.0 \\
\hline " & & B 4 & $2.0-3.0^{\prime \prime}$ & $0.5-1.0$ & $0.5-2.0$ & 1. 0 \\
\hline " & & B 5 & $1.0-2.0$ & $0.5-3.0$ & 2.0 & - \\
\hline Mahon & & & $2.0-3.0$ & $0.5-1.0$ & $3.0-5.0$ & $? * * *$ \\
\hline Sabin & 1 & & 3.0 & $0.5-1.0$ & $0.5-2.0$ & 1.0 \\
\hline
\end{tabular}

* Plaque size in diameter $(\mathrm{mm})$

** $\mathrm{P}$ indicates the very small plaque.

*** The size could not be measured because of the overlapping of plaques

' rough or smooth boundary plaque

" rough boundary plaque 
studies produced a cytopathogenic effect on MK, MS, FL and HeLa cells, the question remained whether those viruses could form the plaque on such cells or not. The experiment was done to clarify the problem. The formation of plaques on the cells and the sizes are indicated in Table 2. The formation and the size of plaques of each virus were different with cells, and especially ECHO 2 virus could form no plaque on any cell used in this experiment. Better formation of plaques was observed in the case of Coxsackie viruses than ECHO viruses.

\section{Heat inactivation of Coxsackie viruses.}

After the fluids containing each of the Coxsackie B1, B2, B3, B4 and B5 were incubated at $50^{\circ} \mathrm{C}$ for $5,10,20$ and 30 minutes, titrations were performed using $\mathrm{FL}$ cell. As a control, the viruses not treated were also titrated.

The results are indicated in Table 3 as the ratio of : titers of non-heated virus / titer of heated virus. Heating at $50^{\circ} \mathrm{C}$ led to rapid inactivation of all viruses tested.

TABLE 3

Heat inactivation of Coxsackie viruses

\begin{tabular}{|c|c|c|c|c|c|c|}
\hline & & $\mathrm{CB}_{1} *$ & $\mathrm{CB}_{2}$ & $\mathrm{CB}_{3}$ & $\mathrm{CB}_{4}$ & $\mathrm{CB}_{5}$ \\
\hline $50^{\circ} \mathrm{C}, \quad 5$ & $\min$ & $3,7^{* *}$ & $>4.0$ & 3.4 & 3.3 & 3. 0 \\
\hline ", 10 & " & 4. 0 & $>4.3$ & $>3.7$ & $>4.3$ & 3.3 \\
\hline " , 20 & " & 4.4 & $>5.0$ & $>3.7$ & 3.6 & 4.0 \\
\hline " 30 & " & $>4.7$ & $>5.0$ & $>3.7$ & 3.6 & 3. 3 \\
\hline
\end{tabular}

* Coxsackie Bl

** titer of non-heated/titer of heated

\section{Variations occurring in the "heat stable" viruses.}

The Coxsackie viruses surviving the above heat treatment were propagated in MK cell monolayers, harvested, and the resulting viruses were designated as "heat stable" viruses. The "heat stable" viruses of Coxsackie B1, B2, B3, B4 and B5 were obtained from samples treated at $50^{\circ} \mathrm{C}$ for $20,20,5,30$ and 30 minutes, respectively. The following experiments were designed to examine the variations which occurred in the "heat stable" viruses, by comparing some properties with the original viruses.

\section{a. Heat inactivation of the "heat stable" viruses.}

The "heat stable" viruses were treated under the same conditions of temperature as the above experiment and titrated with $\mathrm{FL}$ cell. The results were shown in Table 4 together with the results obtained by the parallel experiments of the original viruses. The value of the $\log _{10}$ difference of the titer of heated from that of the non-heated sample are given in the table. The ratios of the values of original to "heat stable" viruses were estimated. The variations obtained by "heat stable" viruses were different according to virus species. That is, the variations related to heat stability occurred inversely, for example, in the case of Coxsackie $\mathrm{B} 3$ and $\mathrm{B} 4$, which became heat labile and resistant, respectively. 
TABLE 4

Heat inactivation of the "heat stable" Coxsackie viruses

\begin{tabular}{|c|c|c|c|c|c|c|c|c|c|c|c|}
\hline & \multicolumn{10}{|c|}{ Titer of non-heated/Titer of heated } \\
\hline & & \multicolumn{2}{|c|}{$\mathrm{CB}_{1} * \mathrm{CB}_{1} \mathrm{H}^{*}$} & \multicolumn{2}{|c|}{$\mathrm{CB}_{2} \quad \mathrm{CB}_{2} \mathrm{H}$} & \multicolumn{2}{|c|}{$\mathrm{CB}_{3} \quad \mathrm{CB}_{3} \mathrm{H}$} & \multicolumn{2}{|c|}{$\mathrm{CB}_{4} \quad \mathrm{CB}_{4} \mathrm{H}$} & \multicolumn{2}{|c|}{$\mathrm{CB}_{5} \quad \mathrm{CB}_{5} \mathrm{H}$} \\
\hline \multirow[t]{5}{*}{$50^{\circ} \mathrm{C}$} & $5 \mathrm{~min}$ & - & - & - & - & - & - & - & - & - & - \\
\hline & 10 & 4. 0 & 3.7 & - & 3. 0 & 0.7 & 4.4 & 1.6 & 1.0 & 2.6 & 3.4 \\
\hline & 20 & $>4.3$ & 3.0 & - & 4.0 & 2.0 & 3.4 & 3.3 & 1.3 & 3.3 & 3. 7 \\
\hline & 30 & 4.3 & 3.3 & - & 4.7 & 2.3 & 3.7 & $>4.3$ & 2.3 & 4.3 & 4. 0 \\
\hline & & \multicolumn{2}{|c|}{$\mathrm{CB}_{1} / \mathrm{CB}_{1} \mathrm{H}$} & \multicolumn{2}{|c|}{$\mathrm{CB}_{2} / \mathrm{CB}_{2} \mathrm{H}$} & \multicolumn{2}{|c|}{$\mathrm{CB}_{3} / \mathrm{CB}_{3} \mathrm{H}$} & \multicolumn{2}{|c|}{$\mathrm{CB}_{4} / \mathrm{CB}_{4} \mathrm{H}$} & \multicolumn{2}{|c|}{$\mathrm{CB}_{5} / \mathrm{CB}_{5} \mathrm{H}$} \\
\hline \multirow[t]{4}{*}{$50^{\circ} \mathrm{C}$, } & $5 \min$ & \multicolumn{2}{|c|}{-} & \multicolumn{2}{|r|}{-} & \multicolumn{2}{|c|}{ - } & \multicolumn{2}{|c|}{-} & \multicolumn{2}{|c|}{-} \\
\hline & 10 & \multicolumn{2}{|c|}{0.3} & \multicolumn{2}{|r|}{-} & \multicolumn{2}{|c|}{-3.7} & \multicolumn{2}{|c|}{0.6} & \multicolumn{2}{|c|}{-0.8} \\
\hline & 20 & \multicolumn{2}{|c|}{$>1.3$} & \multicolumn{2}{|r|}{ - } & \multicolumn{2}{|c|}{-1.4} & \multicolumn{2}{|c|}{2.0} & \multicolumn{2}{|c|}{-0.4} \\
\hline & 30 & \multicolumn{2}{|c|}{1.0} & \multicolumn{2}{|r|}{ - } & & & \multicolumn{2}{|c|}{$>2.0$} & \multicolumn{2}{|c|}{-0.3} \\
\hline
\end{tabular}

* $\mathrm{CB}_{1}$; original Coxsackie $\mathrm{Bl}$ virus

$\mathrm{CB}_{1} \mathrm{H}$; "heat stable" Coxsackie Bl virus

b. Heat stability in the course of multiplication of the "heat stable" viruses.

The original aud the "heat stable" viruses were titrated under the conditions of incubation at $37^{\circ} \mathrm{C}$ and $40^{\circ} \mathrm{C}$ using $\mathrm{MK}$ cell, and the multiplication of both viruses were compared under each temperature condition. As the results illustrate in Table 5 , it seemed that the "heat stable" viruses, compared with the original viruses, are labile to high temperature in the course of multiplication in general.

TABLE 5

Titration of original and "heat stable" viruses at $37^{\circ}$ and $40^{\circ} \mathrm{C}$

\begin{tabular}{|c|c|c|c|}
\hline & \multicolumn{2}{|c|}{ titer at $37^{\circ} \mathrm{C} /$ titer at $40^{\circ} \mathrm{C}$} & \multirow{2}{*}{$\mathrm{NH} / \mathrm{H}$} \\
\hline & $\mathrm{NH} * *$ & $\mathrm{H} * *$ & \\
\hline $\mathrm{CB}_{1} *$ & 2.6 & 2.0 & 0.6 \\
\hline $\mathrm{CB}_{2}$ & -0.4 & 1.4 & -1.8 \\
\hline $\mathrm{CB}_{3}$ & 2.6 & 2.6 & 0 \\
\hline $\mathrm{CB}_{4}$ & 1.6 & $>4.3$ & $<-2.7$ \\
\hline $\mathrm{CB}_{5}$ & 2.3 & $>4.3$ & $<-2.0$ \\
\hline Mahoney & 0.7 & & \\
\hline Sabin-1 & 5.0 & & \\
\hline
\end{tabular}

* $\quad \mathrm{CB}_{1} ;$ Coxsackie B1

$* * \mathrm{NH}$; original virus

$\mathrm{H}$; "heat stable" virus

c. Plaque formation of the "heat stable" viruses.

Plaque forming ability of the "heat stable" viruses were tested. The number 
and the size of plaques formed by the "heat stable" viruses were compared with those formed by the original viruses.

For comparison of the numder of plaques, the value of PFU / TCD 50 was accounted and estimated with the ratio of the value of the "heat stable" to that of the original virus.

TABLE 6

Plaque formation of "heat stable" viruses

(Plaque number)

\begin{tabular}{|c|c|c|c|c|}
\hline & \multicolumn{2}{|c|}{$\mathrm{NH} * *$} & \multicolumn{2}{|c|}{$\mathrm{H} * *$} \\
\hline & $\mathrm{TCD}_{50}$ & PFU & $\mathrm{TCD}_{50}$ & PFU \\
\hline $\mathrm{CB}_{1} *$ & $0.63 * * *$ & $33 * * *$ & 0.32 & 9.5 \\
\hline $\mathrm{CB}_{2}$ & - & - & 3.2 & 4.5 \\
\hline $\mathrm{CB}_{3}$ & 0.32 & 3.3 & 1.6 & 15 \\
\hline $\mathrm{CB}_{4}$ & 0.63 & 10.5 & 3.2 & 9.5 \\
\hline \multirow[t]{3}{*}{$\mathrm{CB}_{5}$} & 6.3 & 19 & 1.6 & 17.8 \\
\hline & \multicolumn{2}{|c|}{$\mathrm{PFU} / \mathrm{TCD}_{50}$} & & \\
\hline & $\mathrm{NH}$ & $\mathrm{H}$ & \multicolumn{2}{|c|}{$\mathrm{H} / \mathrm{NH}$} \\
\hline $\mathrm{CB}_{1}$ & 52.4 & 29.7 & \multicolumn{2}{|c|}{0.57} \\
\hline $\mathrm{CB}_{2}$ & - & 1.4 & \multicolumn{2}{|c|}{-} \\
\hline $\mathrm{CB}_{3}$ & 10.3 & 9.4 & \multicolumn{2}{|c|}{0.91} \\
\hline $\mathrm{CB}_{4}$ & 16.7 & 3.0 & \multicolumn{2}{|c|}{0.18} \\
\hline $\mathrm{CB}_{5}$ & 3.0 & 11.1 & \multicolumn{2}{|c|}{3.70} \\
\hline
\end{tabular}

* $\quad \mathrm{CB}_{1} ;$ Coxsackie B1

* * $\mathrm{NH}$; original virus

$\mathrm{H}$; "heat stable" virus

$* * *$ titer per $1 \mathrm{ml}\left(\times 10^{6}\right)$

TABLE 7

Plaque formation of "heat stable" virus

(Plaque size)

\begin{tabular}{l|cc||c}
\hline & $\mathrm{NH} * *$ & $\mathrm{H} * *$ & $\mathrm{H} / \mathrm{NH}$ \\
\hline $\mathrm{CB}_{1} *$ & $\mathrm{p}-5 * * *$ & $\mathrm{p}-4$ & $1-0.8$ \\
$\mathrm{CB}_{2}$ & - & $\mathrm{p}$ & - \\
$\mathrm{CB}_{3}$ & 0.5 & $0.5-5$ & $1-10$ \\
$\mathrm{CB}_{4}$ & $0.5-2$ & $0.5-3$ & $1-5$ \\
$\mathrm{CB}_{5}$ & $0.5-3$ & $0.5-3$ & 1 \\
\hline
\end{tabular}

$* \quad \mathrm{CB}_{1} ;$ Coxsackie B1

* * NH; original virus

$\mathrm{H}$; "heat stable" virus

*** in diameter ( $\mathrm{mm}$ )

$\mathrm{p}$ indicates the very small plaque. 
The comparisons of the size were done with the ratio of the diameter of plaques of both viruses. The results were indicated in Table 6 and 7 .

Plaque formation of the "heat stable" viruses increased in number in the case of Coxsackie B5 virus, while it decreased in the case of Coxsackie B4 virus.

The size of the plaque was shown to be constant or to have a tendency to increase, especially in the case of the "heat stable" Coxsackie B3 virus.

The results of the experiments above mentioned were summarized in Table 8 to compare the variations of the "heat stable" viruses.

TABLE 8

Variations of the "heat stable" Coxsackie virus

\begin{tabular}{|c|c|c|c|c|c|c|}
\hline & $\begin{array}{r}\mathrm{TCD}_{50}, \mathrm{un} \\
50^{\circ} \mathrm{C}\end{array}$ & $\begin{array}{l}\text { ted } / \mathrm{TC} \\
0^{\prime} \quad 20 \\
* * / \mathrm{H}\end{array}$ & $\begin{array}{l}\text { 50, heated } \\
30^{\prime}\end{array}$ & $\left\{\begin{array}{c}\mathrm{TCD}_{50}, 37^{\circ} \mathrm{C} / \mathrm{TCD}_{50}, 40^{\circ} \mathrm{C} \\
\mathrm{NH} / \mathrm{H}\end{array}\right.$ & $\begin{array}{c}\mathrm{PFU} / \mathrm{TCD}_{50} \\
\mathrm{H} / \mathrm{NH}\end{array}$ & $\begin{array}{c}\text { Plaque size } \\
\mathrm{H} / \mathrm{NH}\end{array}$ \\
\hline $\mathrm{CB}_{1} *$ & 0.3 & $>1.3$ & 1.0 & 0.6 & 0.57 & $1-0.8$ \\
\hline $\mathrm{CB}_{2}$ & - & - & - & -1.8 & - & - \\
\hline $\mathrm{CB}_{3}$ & -3.7 & -1.4 & -1.4 & 0 & 0.91 & $1-10$ \\
\hline $\mathrm{CB}_{4}$ & 0.6 & 2.0 & $>2.0$ & $<-2.7$ & 0.18 & $1-1.5$ \\
\hline $\mathrm{CB}_{5}$ & -0.8 & -0.4 & 0.3 & $<-2.0$ & 3.7 & 1 \\
\hline $\begin{array}{l}* \\
* *\end{array}$ & $\begin{aligned} \mathrm{CB}_{1} ; & \text { Coxsa } \\
\mathrm{NH} ; & \text { origir } \\
\mathrm{H} ; & \text { "heat }\end{aligned}$ & $\begin{array}{l}\mathrm{BI} \\
\text { irus } \\
\text { ole" }^{\prime \prime} \mathrm{vi}\end{array}$ & & & & \\
\hline
\end{tabular}

\section{DISCUSSION}

It is known that ECHO viruses grow in monkey kidney cells, human amnion cells, Maben carcinoma cells, and HeLa cells; and Coxackie B viruses in monkey cells, HeLa cells and pig kidney cells ${ }^{1}$. The comparable cell susccptibility of these viruses was tested in the present study by using monkey kidney (MK) cells, and three established cell lines of MS cells (monkey kidney origin), FL cells (human amnion origin) and HeLa cells (human carcinoma origin). The experiment points out that the above four cells are susceptible to all viruses tested. ECHO 2, 11 and 12 and Coxsackie B2 viruses show comparably equal titers for each of the cells, while the other viruses are more or less different with the cells used. Thus, it seems that MK and MS cells are more susceptible to these viruses than others, indicating that it is advantageous for titrating the viruses with MK or MS cells.

In the growth experiment using five types of ECHO viruses, four types of Coxsackie B group viruses, and three cell cultures, MK, MS and FL cells, it was found that the viruses began to grow after about 6 hours from adsorption. This agrees with the result of Boring and Levy for Coxsackie B1-HeLa cell system². Maximum growth is reached by the following incubation of approximately 6 hours where viruses increase almost exponentially. Better yields of viruses were shown in MS and FL cells than MK cell. The average yield of each virus by MS and FL cells was approximately 300 particles per infected cell, though only about one 
tenth by MK cell, such a low yield remaining to be investigated.

The growth of viruses were examined as to the total of intracellular plus extracellular viruses in the present study, Rhim et al. ${ }^{3)}$ pointed out that the extracellular ECHO 10 virus was always about an average of $20 \%$ of the total, while maturation proceeded in the MK cell. In a preliminary experiment, not presented in this report, it was found that ECHO 3 virus showed a delayed cytopathogenic effect and a low titer for the FL cell as compared with the MS cell, despite the fact that the virus was produced to the same extent by both cells. This suggests agreement with the result obtained by the ECHO 10-MK cell experiment, in at least the case of the ECHO 3-FL cell system.

Though the viruses studied are all cytopathogenic for cells used, certain cases form no plaques, and among them ECHO 2 virus fail to produce any plaques in the four cells used. Rhim and Melnick ${ }^{4}$ recently reported on the modified serumfree agar overlay medium for ECHO 10 for production of plaque on the MK cell. In addition, they indicaied the inhibitory effect of neutral red contained in the agar overlay. The authors' failure to develop plaques might be based on the same reason. The shape of plaques is different with reference to the combination of virus and cell, and does not always agree with the report of Hsiung and Melnick ${ }^{5}$ on the classification of ECHO viruses.

Coxsackie B viruses are inactivated rather rapidly by heat treatment, but survive to the extent that the viruses can further propagate in cell cultures, even after treatment for 5 to 30 minutes at $50^{\circ} \mathrm{C}$. The "heat stable" virus thus obtained, results in acquiring changes in various characteristics in comparison with the original viruses, as summarized in Table 8. Experiments showed that the heat stability of viruses is not necessarily obtained by heat treatment.

It is noteworthy to indicate that there is no parallelism between the variations in reference to the heat stability of free virus and of virus propagation in the cell. This is interesting from the viewpoint of the same phenomenon as found in the experiments on heat stability and the $\mathrm{T}$-marker test performed for attenuated and virulent strains of poliovirus ${ }^{6}$. To make clear the variations on the plaque forming ability, plaque forming units per infectious particle ( $T C D_{50}$ ) were compared between original and "heat stable" viruses. The result showed the remarkable changes in plaque forming ability. Coxsackie B4 reduced the ability one-fourth to one-fifth, while Coxsackie B5 increased it about four times.

In respact to plaque size, only the "heat stable" virus of Coxsackie B4 showed a remarkable result as the size increased 1 to 10 times greater in diameter. It is not yet clear why the plaque becomes large. It may depend on the increment of the burst size $^{7}$ or the shortening of the maturation time ${ }^{8}$.

\section{SUMMARY}

MK, MS, FL and HeLa cells are susceptible to ECHO and Coxsackie B viruses. Some types of viruses do not possess the ability to form plaque under the conditions adopted in this study.

The Coxsackie viruses surviving heat treatment has variations as to heat stability in the state of free virus or propagating virus in cells, plaque forming ability 
and plaque size. The variations are different with the type of viruses.

\section{A.CKNOWLEDGMENT}

Grateful acknowledgement is made to prof. Yoh Nakagawa, for his interest and guidance in this investigation.

\section{REFERENCES}

1. J.L. Melnick : Advances in the study of the enterovirus, in "Progress in Medical Virology, Vol. 1" New York (1958) pp 75 and 81.

2. W. D. Boring and R.S. Levy : Studies on the Production of B1 Coxsackie Virus by HeLa Cells. J. Immunol. 88, 394-400, 1962.

3. J.S. Rhim, K. O. Smith and J. L. Melnick : Complete and Coreless Forms of Reovirus (ECHO 10). Ratio of Number of Virus Particles to Infective Units in the OneStep Growth Cycle. Virology, 15, 428-435, 1961.

4. J.S. Rhim ANd J. L. Melnick : Plaque Formation by Reovirus, Virology, 15, 80-81, 1961.

5. G. D. Hsiung and J.L. MeLnick : Ophan viruses of man and animals. Ann. New York Acad. Sci., 70, 342-360, 1958.

6. M.Shingu and S. Yamamoto : in press.

7. R. I. Carp and H. Koprowski : Mutation of Type 3 Poliovirus with Nitrous Acid. Virology 17, 99-109, 1962.

8. C. Wallis AND J.L. Melnick : Magnesium chloride enhancement of cell susceptibility to poliovirus. Virology 16, 122-132, 1962. 